Egypt. Acad. J. Biolog. Sci., 4(1):43-53 (2012)

Email: egyptianacademic@yahoo.com

Received: 11/3/2012
C. Physiology \& Molecular Biology

ISSN: 2090-0767

www.eajbs.eg.net

\title{
Variation in growth hormone (GH) of gene in exon sequence in three salmon
} types

\author{
Abolhasan Rezaei \\ Department of Genetics-School of Basic Science, Tonekabon Branch, Islamic Azad \\ University, Tonekabon, Iran \\ a.rezaei@tonekaboniau.ac.ir
}

\begin{abstract}
We aimed to identify polymorphisms in the coding regions of the Salmo trutta caspius (s. t. caspius) growth hormone gene for comparison of the rate homology between sequences cited regards salmonids, because the variation between sequences of exons is very important at finally can change in the rate of expression of gene growth hormone, however this gene identified by marker genetics in salmonids, and in those of Salmo salar (s. salar) and salmo trutta (s. trutta). This single copy nuclear gene contains six exons, that the length of the exon fragments almost 1900 base pairs between nucleotide 35 and 1907. In s. t. caspius. Selective PCR reaction, and sequenced the products, that including fragments of from first to end of the GH gene. We also describe a novel polymorphism of the six exons fragment, these fragments indicated for studies regards evolution of fish GH genes, phylogeny of fishes, and genetic selection. The segments of GH exon were analyzed by DNAMAN program genetics. The results are shown, there were almost 90\%, homology between the first three exons of S. t. caspius and S. salar accession number (AY614002.1) Regards other Salmons; S. salar (Accession number, M21573.1) and Rainbow trout there weren't any homology, exon fragments second, third, fourth, fifth and sixth, the homology were high (almost 90-95\%), however between fragments of salmons, the rate of homology were high but the length of fragments between salmons were different. The length of fragments in s. salar more than other salmons including $R$. trout and S. t. caspius.
\end{abstract}

Keywords: Salmo trutta caspius, Growth hormone gene. Salmo salar, Rainbow trout (Salmo trutta), exon

\section{INTRODUCTION}

A fish species which has been intensively studied with allozyme (Ferguson et al., 1989), mitochondrial (Breatchez et al., 1992; Ovenden et al., 1993), and microsatellite markers (Estoup et al., 1993). We studied regards Growth hormone gene. The Growth rate of fish is an important factor in aquaculture (Agelon et al., 1988; Gross et al., 1995; Gross et al., 1996). Growth hormone (GH) is involved in linear growth, food conversion and appetite in fish stimulates somatic growth in vertebrates including teleosts. The use of GH for enhancing growth rate of fishes in aquaculture prompted the cloning and characterization of the $\mathrm{GH}$ genes from different fish species. These have been found to be more variable than mammalian GH genes. For example, carp species such as common carp (Chiou et al., 1990), grass carp (Ho., 1991; Zhu et al., 1992), and silver carp (Hong and Schartl, 1993), and catfish (Tang et al., 1993), contain five exons, as found in mammals and birds, whereas, the Salmonids, Rainbow trout (R.trout) (Agelon et al., 1993; ,Gross et al., 1995; Gross et al., 1996), Atlantic salmon (Johanson et al., 1989;Male et al., 1992), chinook salmon (Du et al., 1993), sockeye salmon (Devlin et al., 1993), tilapia (Breatchez et al., 1992), flounder (Tanaka et al., 1995), yellowtail (Ohkubo et al., 1996), 
barramundi (Yowe and Epping, 1995), and pufferfish (Venkatesh et al., 1997). Contain six exons, and the gene in different species Salmonids also of varies from $3.5 \mathrm{~kb}$ in length. Variation in the length of exons and introns being low. Identification of $\mathrm{GH}$ gene allelic variation may provide useful genetic markers for selection of fish with desirable growth trait. The Salmo trutta caspius species is a marine teleost that is very important in the industrial aquaculture. This species is inhabiting Rivers around the Caspian sea, especially in the west and southwest of the Caspian sea regions. We analysed here on the sequence of GH gene, the rate of single nucleotide variation, also the studies of microsatellite fragments in the exons of Salmo trutta caspius and compared that with sequences for Salmo salar and other bonyfishes available on GeneBank. The results are shown that there are high homology between sequences of exon, but the length of GH exons in the Salmo trutta caspius more than shorter Salmo salar and other bonyfishes.

\section{MATERIALS AND METHODS}

Salmo trutta caspius were obtained from Dohezar and Sardabroud-TonekabonIran. Samples including 14 numbers. They were anaesthetized with MS2220 and extracted of blood from caudal vein. Blood samples $(2-5 \mathrm{ml})$ were removed from the fish via caudal puncture (G.18 needle) using a heparinized syringe (as an anticoagulant for blood sampling) after using MS222, $(1: 10,000)$ as an anaesthetic to minimize stress. The genomic DNA was extracted from Bloods sample. Were used proteinase $\mathrm{K}$ for digestion and phenolchloroform for extraction (Sambrook et al., 1989). The concentration of DNA was checked through spectrophotometrically under wave length of A260/280 nanometer. Moreover, the samples of Salmons are very rarely, so for getting more DNA templates were extracted DNA by the phenolchloroform extraction method. DNA quality was checked by 0.8 percent agarose gel electrophoresis. For getting good quality DNA, those devoid of smear were used for the study of PCR polymorphism.

PCR Amplification: A $1.9 \mathrm{~kb}$. fragment of the growth hormone gene that contains the six exons from first to end of the GH gene, designed three pairs of primer using the primer walking technique. These had the sequence:

\section{Forward primer:}

ACATACTCAACCGACCACCGCACTT TCAAG

Reverse primer: GTGACAGGTCCACTCTGCTATTCA

\section{Forward Primer:}

GTAAATAGGGAATCTCAAGCTGT

Reverse Primer:

CTCAAATACTTCTAGTAAGTTGA

Forward primer:

CATCACTAATATTGACTATATCAG

Reverse primer:

CAGATTAGGCCTTGCCCTGCACTGA

PCR was carried out in a final volume of $50 \mu \mathrm{l}$ reaction mixture containing 80-100 ng DNA, $5 \mu 1$ 10X PCR assay buffer, $2 \mu 1.2 .5 \mathrm{mM}$ of each dNTP, $0.5 \mu 1$. $3 \mathrm{u} / \mu 1$. Taq DNA polymerase, 2 $\mu 1 .(100 \mathrm{ng} / \mu \mathrm{l})$ of each primer and $37.5 \mu \mathrm{l}$ water (D.D.W). PCR reactions were carried out in a thermocycler (PTC-200, MJ Research, USA). The PCR reaction used 10 microgram PCR reactions contained: $1 \mu 1$ template DNA, $2 \mu 1$ forward primer $(100 \mathrm{ng} / \mu \mathrm{l}), 2 \mu \mathrm{l}$ reverse primer (100 ng/ $\mu 1), 2 \mu 1 \mathrm{dNTP} \operatorname{mix}(2.5 \mathrm{mM}$ each), $5 \mu 1$ 10X ChromTaq Assay buffer, $0.5 \mu 1$ ChromTaq enzyme $(3 \mathrm{U} / \mu \mathrm{l})$, Water $37.5 \mu \mathrm{l}$, in a total volume, $50 \mu 1.94^{\circ}$ of $5 \mathrm{~min}, 35$ cycles of $94^{\circ} \mathrm{C} 30 \mathrm{Sec} ., 55^{\circ} \mathrm{C} 30 \mathrm{Sec}$, and $72^{\circ} \mathrm{C} 1 \mathrm{~min}$. Two to ten $\mu 1$ of each PCR reaction were run on $0.8 \%$ agarose gels in TAE buffer containing ethidium bromide. One $\mu 1$ 500bp, DNA ladder (Gibco-BRL) was used as a size standard. The PCR products were separated by electrophoresis in a TAE agarose gel containing ethidium bromide using standard protocols(19) The desired PCR product band was excised using a sterile razor blade or scalpel (band was visualized in a medium or long wavelength (e.g., $\geq 300 \mathrm{~nm}$. UV light). The agarose slice was transferred to a $1.5 \mathrm{ml}$ microcentrifuge or screw cap tube and then 
purified by Gel Extraction Spin-50 (RKT33) kit, Chromous Geni-India. Quantification was by loading one $\mu \mathrm{l}$ of eluted sample in $1 \%$ agarose gel and comparing with standard molecular marker (500 bp DNA ladder). Only samples with good concentration $(>50 \mathrm{ng} / \mu \mathrm{l})$ were selected and subjected to sequencing. Sequence data were analyzed mostly by DNAMAN program genetics and BLAST network system. The database search of sequences for a possible match to the DNA sequence of growth hormone gene was conducted using the BLAST algorithm available at the National Center for Biotechnology Information (NCBI).

\section{RESULTS}

Identification and characterization exon fragments growth hormone gene:

The PCR amplification generated $\begin{array}{lllll}\text { approximately } & \text { a } & 1.9 & \mathrm{~kb} & \text { This }\end{array}$ polymorphism was confirmed by nucleotide sequencing. (35..44, 513..652, 804..920, 1064..1219, 1474..1620, 1845..1907). (Fig.1). The nucleotide sequences as well as deposited in (Gene Bank, accession number, JN241634.1) have been explained in this study.

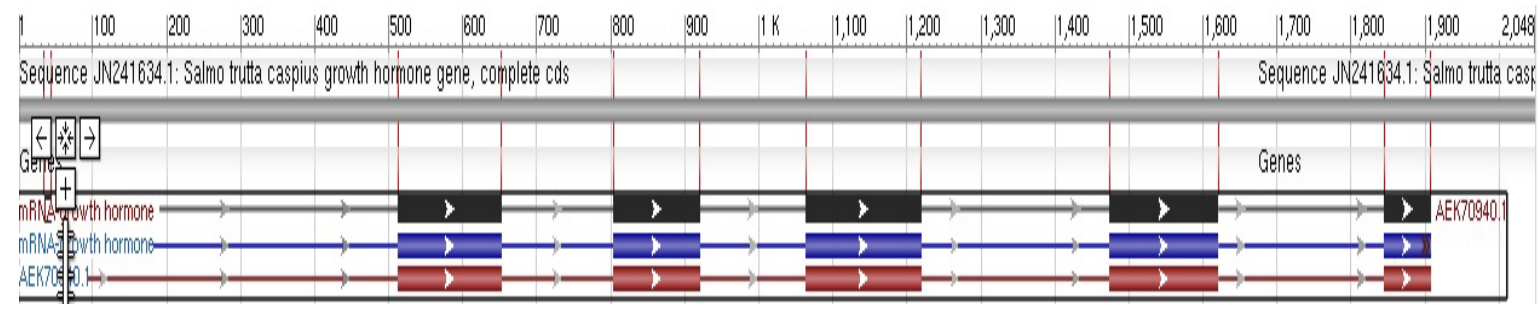

Fig. 1: Structure of graphical growth hormone gene in the Salmo trutta caspius (Accession number: JN241634.1). Exons are labeled, Exon1, Exon 2, Exon 3, Exon 4, Exon 5 and Exon 6. Size is indicated one base pairs (bp.). Positions and directions of exons are shown by color arrows.

Comparison of sequencing fragments exon GH gene Salmo trutta caspius with other Salmons: Salmo trutta caspius GH1 gene have six exons in the full length of $\mathrm{GH}$ gene. The exons have high homology with other Salmons but the length of $\mathrm{GH}$ shorter than Salmons GH gene. The sequences of first exons for Salmo trutta caspius GH gene with other species of Salmons has been depicted in. First exon has ten nucleotides in the full length of $\mathrm{GH}$ gene, that started from $35^{\text {th }}$ base to $44^{\text {th }}$ base. The comparisons of result are shown that a similarity (10 -nt consensus) between first exon of $\mathrm{GH}$ in the Salmo trutta caspius and Salmo salar, but regarding Rainbow trout there was not any nucleotides in the spanning of the first exon. (Fig. 2). There are in the Gene Bank eleven reports about full length of Salmo salar GH gene, we aligned sequences (Accession number: AY61402, AY61403, AY61404, AY61405, AY61406, AY61407, AY61408, AY61409, AY614010, M21573.1, and X61938.1).

\section{S.s.(AY614002.1) TAAAAATGGGACAAGGTAAG 652 \\ S. t. Caspius(E1) ..... ATGGGACAAG . . . . 10 \\ S.S.(X61938.1) TAAAAATGGGACAAGGTAAG 705 \\ R.t.(M22731.1) …......... \\ S.S.(M21573.1) gAgAAAaaaatgggacaAgG 681}

Consensus

Fig. 2: The sequences of first exon of GH gene in the Salmo trutta caspius, Salmo salar (S.s.) and Rainbow trout (R.t.)

The results are shown there are high homology between sequences of Accession number from AY61402 to AY614010 and X61938.1. but with Accession number M21573.1, homology was different. In related to we selected three sequences
(AY61402 and X61938.1) and M21573.1, regarding the Rainbow trout, there is one report about full length of mRNA of GH gene in the Gene Bank. So, we selected and were aligned with fragments of exon. Regarding to first exon, the results also 
were aligned with homology tree in the DNAMAN program genetics (Fig. 3). The among of homology between Salmo trutta caspius and sequences of Salmons except Accession No. M21573.1 is very high, but regarding Rainbow trout and Salmo salar Accession no. M21573.1 we did not find any significant homology in this region. The start codon ATG was began from nucleotide of 35 but in Salmo salar (AY614002.1) from nucleotide of 638 and Salmo salar (X61938.1) nucleotide of 691. Regarding to Salmo salar (M21573.1) in this region was not observed any start codon. Regarding to Second exon, in the Salmo trutta caspius GH gene has 104 nucleotides.

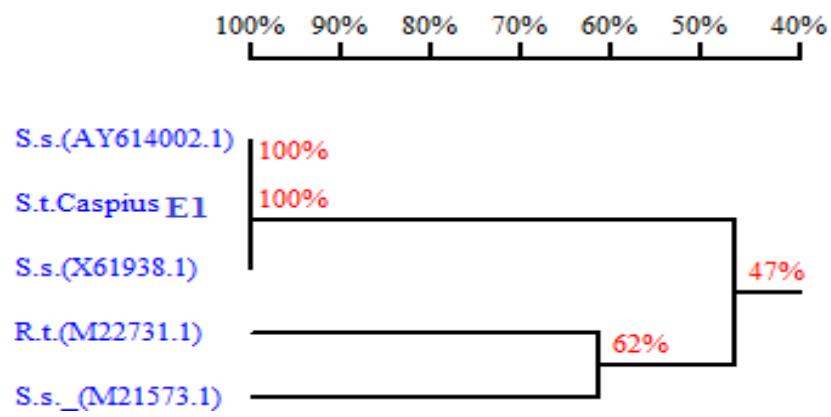

Fig. 3: Homology tree analysis of sequences of the first exon from Salmo trutta caspius, Salmo salar (S.s.) and Rainbow trout (R.t.).

The results were aligned with the Salmons. Also regarding Rainbow DNAMAN program genetics (Fig. 3), we trout the results same with first exon. are shown that there were high homology Approximately, there were rich of between Salmons except Salmo salar (Acc.no. M21573.1) and Rainbow trout we didn't find any homology with second exon. The second exon in the Salmo trutta caspius $\mathrm{GH}$ gene is much shorter than the corresponding second exon for nucleotides of A-T-C repeated in the length of second exon that can be annotated mini and microsatellites regarding GH1 gene in the second exon (Fig. 4).

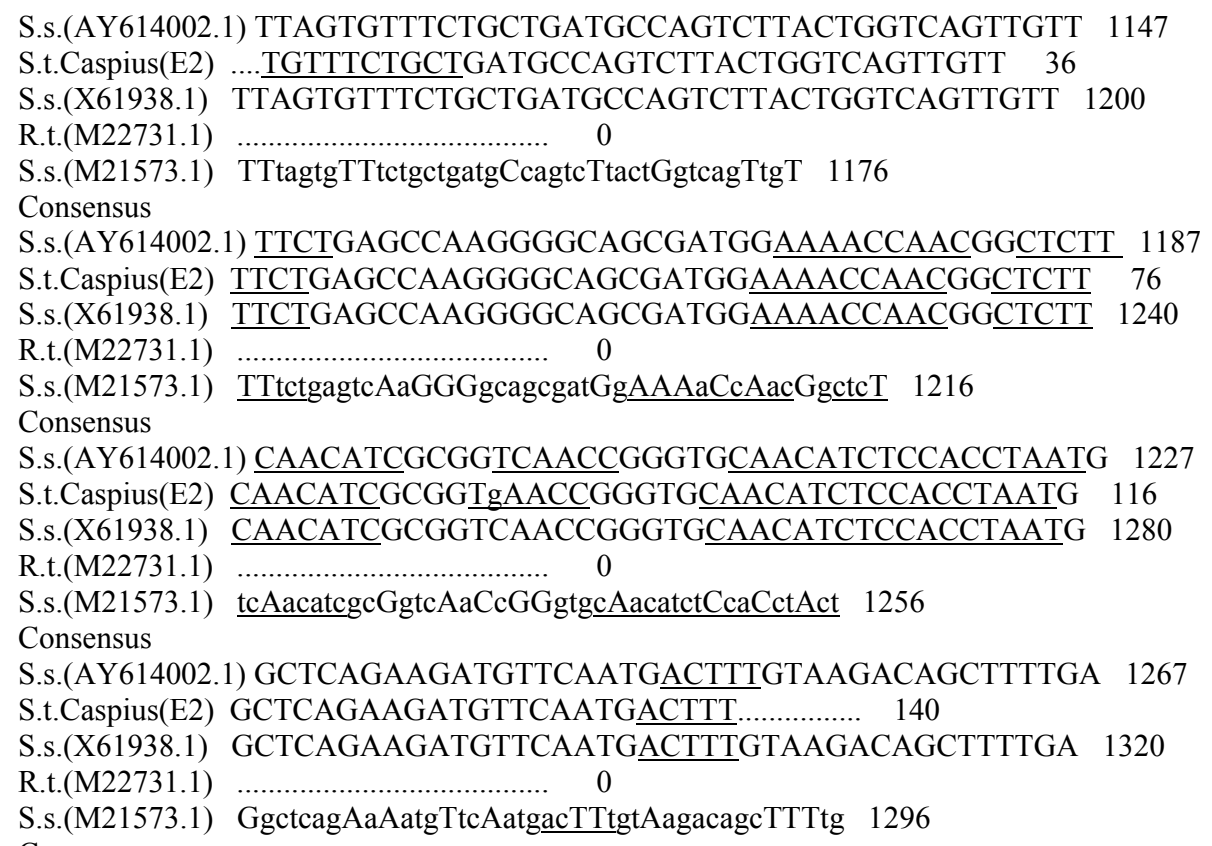

Fig. 4: Sequences of second exon of Salmo trutta caspius, Salmo salar (S.s.) and Rainbow trout (R.t.). Compared sequences of salmons are underlined. 
Egypt. Acad. J. Biolog. Sci., 4(1):43-53 (2012) Email: egyptianacademic@yahoo.com Received: 11/3/2012
C. Physiology \& Molecular Biology

ISSN: 2090-0767

www.eajbs.eg.net

Also the results aligned with tree homology DNAMAN program genetics (Fig. 5). Regarding to third exon, we aligned also Salmons sequences and

Rainbow trout, the results are shown the homology between sequences except Rainbow trout were very high.

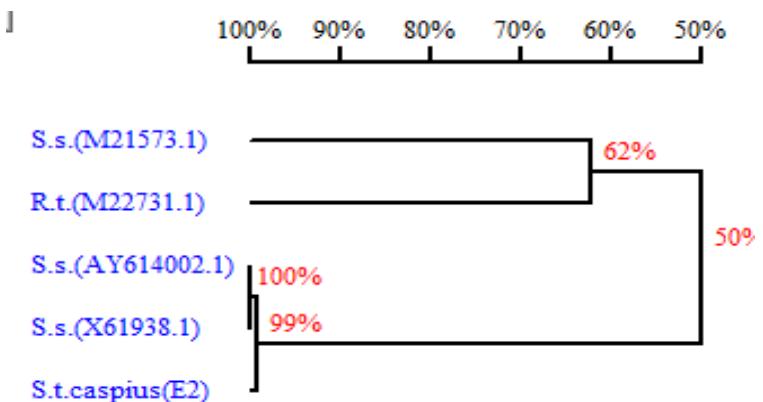

Fig. 5: Homology tree analysis of sequences of the second exon from Salmo trutta caspius, Salmo salar (S.s.) and Rainbow trout (R.t.).

Also, about markers we find caspius is 117 nucleotides while in the repeated A-T-C nucleotides belong to Salmons was 160 and Rainbow trout was mini and microsatellite in the length of not there any nucleotides in the length. third exon that same second exon. The The third exon mutations between length of third exon in the Salmo trutta Salmons was very poor (Fig. 6).

S.S. (M21573.1)

R. t . (M22732.1)

S.S. (AY614002.1)

S.S. (X61938.1)

S. t.caspius(E3)

Consensus

S.S. (M21573.1)

R.t . (M22732.1)

S.S. (AY614002.1)

S.S. (X61938.1)

S. t. caspius(E3)

Consensus

S.S. (M21573.1)

R. t . (M22732.1)

S.s. (AY614002.1)

S.S. (X61938.1)

S. t.caspius(E3)

Consensus

S.S. (M21573.1)

R. t . (M22732.1)

S.S. (AY614002.1)

S.S. (X61938.1)

S. t.caspius(E3)

TGATTTTGTGCAGGAAGGCACCCTGTTGTCTGATGAACGC

TGATTTTGTGCAGGAAGG $\ldots \ldots \ldots \ldots \ldots \ldots \ldots \ldots$

1444

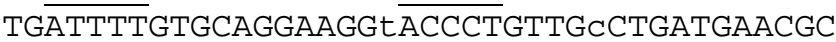
$\ldots \ldots \ldots . . .$. GAAGGCACCCTGTTGCCTGATGAACGC

AgACAgCTGAACAAGATATTCCTGCTGGACTTCTGTAACT 1484

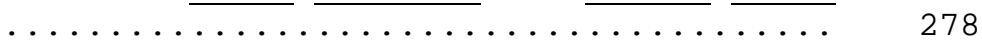

AGACAGCTGAACAAGATATTCCTGCTGGACTTCTGTAACT 1460

AGACAGCTGAACAAGATATTCCTGCTGGACTTCTGTAACT 1512

$\begin{array}{lr}\text { AGACAGCTGAACAAGATATTCCTGCTGGACTTCTGTAACT } & 67\end{array}$

CGGACTCCATCGTGAGCCCAATCGACAAGCAGGAGACTCA 1524

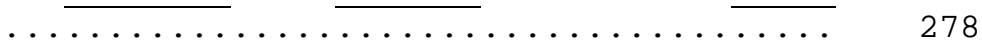

CtGACTCCATCGTGAGCCCAATCGACAAGCttGAGACTCA 1500

CtGACTCCATCGTGAGCCCAATCGACAAGCttGAGACTCA 1552

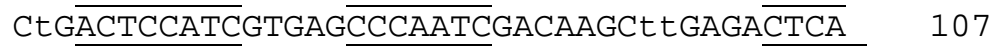

Consensus

Fig. 6: Sequences of the third exon in Salmo trutta caspius, Salmo salar (S.s.) and Rainbow trout (R.t.) compared sequences are underlined.

We also discussed third exon with homology tree (Fig. 7), that results denoted among of homology between Salmons except Rainbow trout and Salmo salar accession number (M21573.1). About fourth, fifth and sixth exon also there were same results, but regarding Rainbow trout we found strong homology in the fourth exon also the length of fourth exon in the Salmo trutta caspius was 157 nucleotides 
and in the Rainbow trout was 165 was different that it is not significantly. nucleotides that only seven nucleotides

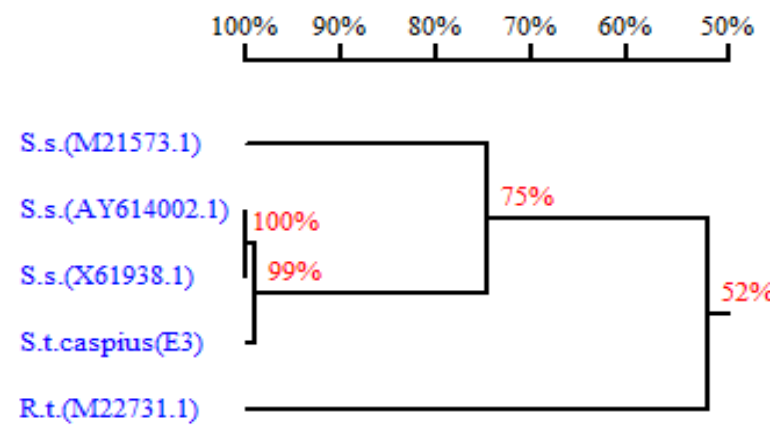

Fig. 7: Homology tree analysis of sequences of the third exon in Salmo trutta caspius, Salmo salar (S.s.) and Rainbow trout (R.t.).

However the results are shown the exon fragments of Salmons were longer than Salmo trutta caspius but the homology in the all of fragments were high. (Figs. 8, 9, 10). These fragments also aligned with tree homology DNAMAN program (Figs. 11, $12,13)$. The fragments had regions of mini and microsatellites that were repeated A-T-C nucleotides.

S.S. (M21573.1)

R.t . (M22732.1)

S. t.caspius(E4)

S.S. ( AY614007.1)

S.S. (AY614002.1)

Consensus

S.S. (M21573.1)

R.t. (M22732.1)

S. t.caspius(E4)

S.s.( AY614007.1)

S.S. (AY614002.1)

Consensus

S.S. (M21573.1)

R.t. (M22732.1)

S. t.caspius(E4)

S.s.( AY614007.1)

S.S. (AY614002.1)

Consensus

S.S. (M21573.1)

R.t . (M22732.1)

S. t.caspius(E4)

S.S. ( AY614007.1)

S.S. (AY614002.1)

Consensus

S.S. (M21573.1)

R.t. (M22732.1)

S. t.caspius (E4)

S.s. ( AY614007.1)

S.S. (AY614002.1)

Consensus

Fig. 8: Sequences of the fourth exon in Salmo trutta caspius, Salmo salar (S.s.)and Rainbow trout (R.t) compared sequences are underlined.

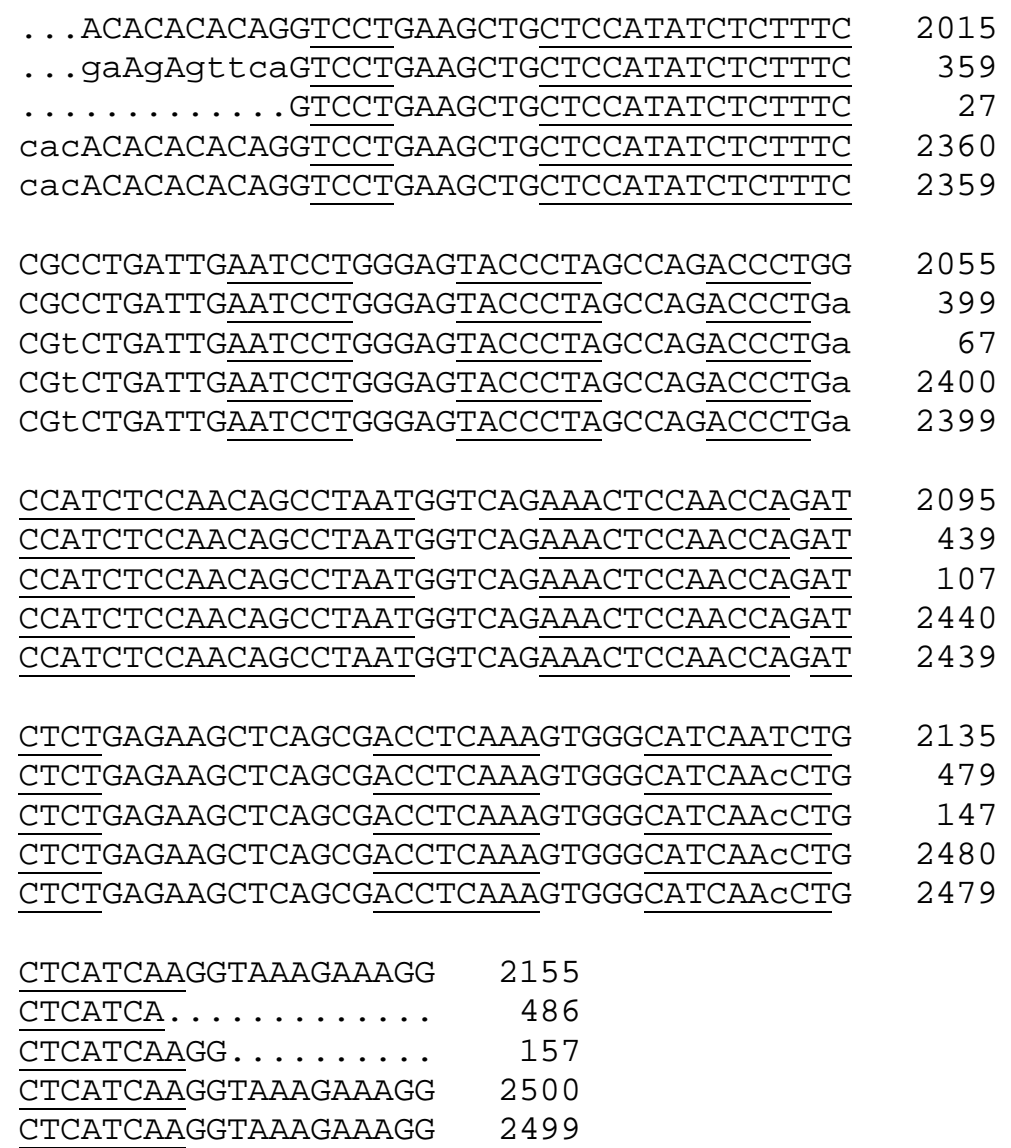

2479 
S.S. (M21573.1)

R. t. (M22732.1)

S.s. (AY614002.1)

S. t. caspius (E5)

S.s. (X61938.1)

Consensus

S.S. (M21573.1)

R. t . (M22732.1)

S.s. (AY614002.1)

S. t.caspius(E5)

S.S. (X61938.1)

Consensus

S.S. (M21573.1)

R.t . (M22732.1)

S. t.caspius(E5)

S.S. (X61938.1)

Consensus

S.S. (M21573.1)

R. t . (M22732.1)

S.s. (AY614002.1)

S. t. caspius(E5)

S.S. (X61938.1)

Consensus

Fig. 9: Sequences of the fifth exon in Salmo trutta caspius, Salmo salar (S.s.) and Rainbow trout (R.t.) compared sequences are underlined.

S.S. (M21573.1)

R.t. (M22732.1)

S. t.caspius (E6)

S.s. ( AY614007.1)

S.s. (AY614002.1)

Consensus

S.S. (M21573.1)

R. t . (M22732.1)

S. t.caspius(E6)

S.s.( AY614007.1)

S.s. (AY614002.1)

Consensus

Fig. 10: Sequences of the sixth exon in Salmo trutta caspius, Salmo salar (S.s.) and Rainbow trout (R.t.) compared sequences are underlined.
3719

667

32

4003

4011

3759

687

63

4043

4051

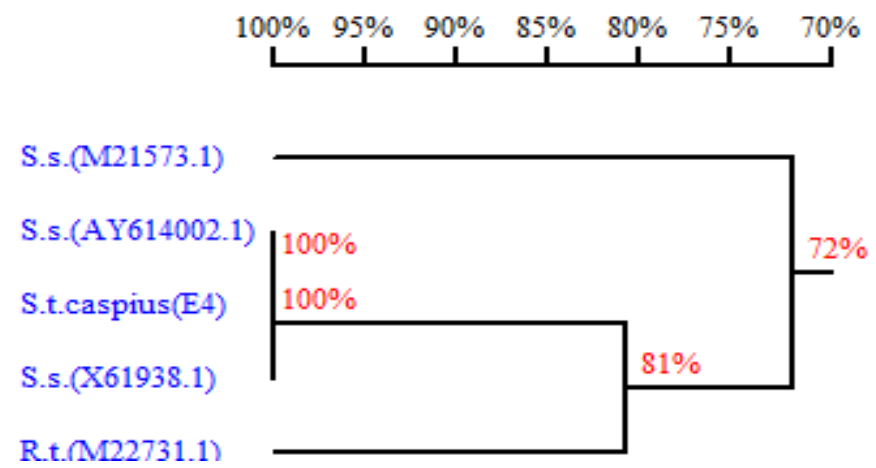

Fig.11: Homology tree analysis of sequences of the fourth exon in Salmo trutta caspius, Salmo salar (S.s.) and Rainbow trout (R.t.). 

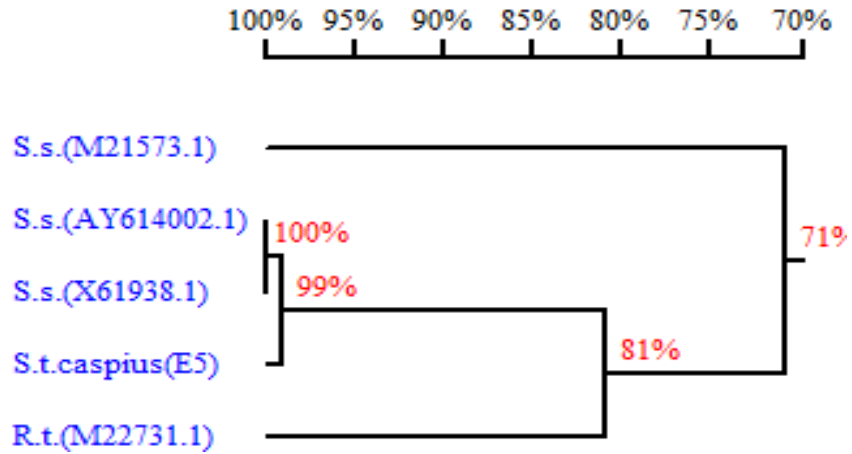

Fig. 12: Homology tree analysis of sequences of the fourth exon in Salmo trutta caspius, Salmo salar (S.s.) and Rainbow trout (R.t.).

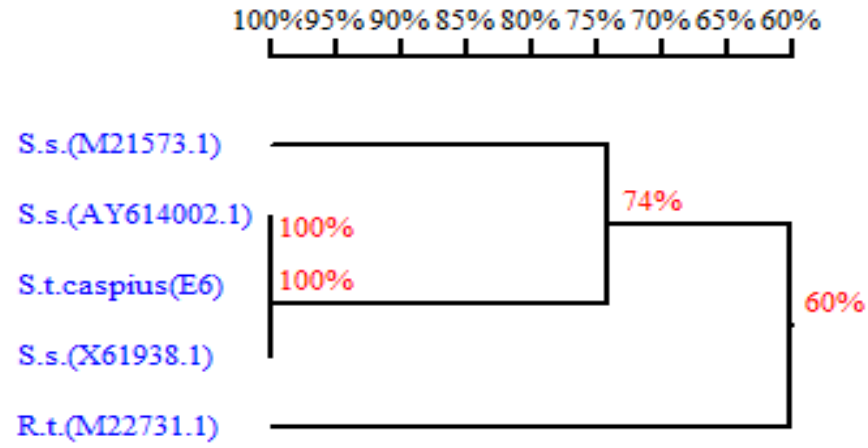

Fig.13: Homology tree analysis of sequences of the fourth exon in Salmo trutta caspius, Salmo salar (S.s.) and Rainbow trout (R.t.).

The ATG codon started in the same region from S.t.caspius, S.s. (AY614002.1 and X61938.1), but for S.s. (M21573.1) and R.t. there was no ATG start codon in this region.

The homology between Salmo trutta caspius and Salmo salar Accession numbers, AY614002.1 and Salmo salar, Accession number, X61938.1 was almost $100 \%$, and between Rainbow trout and Salmo salar, accession number M21573.1 was almost $62 \%$. That the rate of varioation was almost high.

The homology sequences, except R.t. were be specific high. The repetitive sequences of nucleotides (underlined fragments) in S. salar and S.t.caspius denote there are mini and microsatellites in the length.

The homology between Salmo trutta caspius and Salmo salar Accession numbers, AY614002.1 and Salmo salar, Accession number, X61938.1 was almost $100 \%$, and between Rainbow trout and Salmo salar, Accession number,
M21573.1 62\%. That the rate of varioation was almost high.

The homology between salmo salar and salmo trutta caspius was high but regards Rainbow trout (R.t.) the homology was low. The repetitive sequences of nucleotides (underlined fragments) in S. salar and S.t.caspius denote there are mini and microsatellites in the length.

Homology between Salmo trutta caspius and Salmo salar Accession numbers, AY614002.1 and Salmo salar, X61938.1 was almost $100 \%$, and between Rainbow trout and Salmo salar, accession number M21573.1 was almost $75 \%$. That the rate of varioation was almost high.

The homology between salmo salar and salmo trutta caspius and Rainbow trout (R.t) was high. The repetitive sequences of nucleotides (underlined fragments) in S. salar, S. t. caspius and Rainbow trout denote there are mini and microsatellites in the length. 
The homology between salmo salar and salmo trutta caspius and Rainbow trout (R.t.) was high. The repetitive sequences of nucleotides (underlined fragments) in $S$. salar, $S$.t. caspius and Rainbow trout denote there are mini and microsatellites in the length.

The homology between salmo salar and salmo trutta caspius and Rainbow trout (R.t.) was high. The repetitive sequences of nucleotides (underlined fragments) in S. salar, S.t.caspius and Rainbow trout denote there are mini and microsatellites in the length.

The homology between Salmo trutta caspius and Salmo salar Accession numbers, AY614002.1 and Salmo salar, X61938.1 was almost $100 \%$, and between Rainbow trout and Salmo salar, accession number M21573.1 was almost $81 \%$. That the rate of varioation was almost high.

The homology between Salmo trutta caspius and Salmo salar Accession numbers, AY614002.1 and Salmo salar, X61938.1 was almost $100 \%$, and between Rainbow trout and Salmo salar, accession number M21573.1 was almost $81 \%$. That the rate of varioation was almost high.

The homology between Salmo trutta caspius and Salmo salar Accession numbers, AY614002.1 and Salmo salar, X61938.1 was almost $100 \%$, and between Rainbow trout and Salmo salar, accession number M21573.1 was almost $81 \%$. That the rate of varioation was almost high.

\section{DISCUSSION}

This study describes the detection of variation GH gene at single copy nuclear genes in Salmo trutta caspius. Therefore the Growth hormone gene is a potential target for studies of genetic variation in connection with studies of growth traits (Gross et al., 1995; Gross et al., 1996; Harvey et al., 1995). We studied variation within exons of GH1 gene by amplification and sequencing of the full length of GH gene, especially regions of exons. For getting full sequences of exon we designed six pair of primers from first to end of GH gene. In related to we selected from all of Salmonids GH gene, specially, Salmo salar and Rainbow trout, around eleven full sequences $\mathrm{GH}$ that reported Gene Bank. These specific primers followed to synthesis around $1.9 \mathrm{kbp}$ for Salmo trutta caspius. The results were interestingly for us. Because the each six exons in Salmo trutta caspius had been high homology with ten sequences of Salmo salar exception of Salmo salar Accession number M21573.1. That we could not understand about it, however among of homology between Salmons sequences were very high. Regarding Rainbow trout, GH gene has 1171 bp mRNA sequence in the Gene Bank. However the length of sequence in the Rainbow trout was shorter than exons of Salmo trutta caspius but the homology approximately was significant. The discussion regarding exons fragment with a specific primers pair followed by eleven sequences Salmo salar and also one sequence from Rainbow trout in the Gene Bank reported. Regarding the sequences of $\mathrm{GH}$ gene, the among of variation of exon fragments are very important, The relationships between among the genera in the subfamily Salmoninae have been controversial. The analyses of this project and other same projects showed that phylogenesis based on the GH exons strongly supported a sister relationship between the genus Salmoninae and other bony fishes. However we should be more researches regarding the markers of genetic related to Salmons.

\section{CONCLUSION}

We have identified regions of growth hormone gene in Salmo trutta caspius that could be a potential genetic markers for Salmonids. Moreover, the species of Salmo trutta caspius in Caspian Sea is very rarely. So, the 
studies regards these fishes are very important. Differences in trait association of the genetic markers may exist among different populations. More tests are needed in other populations of bony fishes to variety associated effects of genetic marker, as well as the effects of the other polymorphisms in the growth hormone and growth hormone gene receptor genes. However the growth hormone gene traits more will be transformed from paternal, So, is better the studies on the other genes markers for example mitochondrial genomics that is associated with maternal traits (Breatchez et al., 1992; Ovenden et al., 1993).

\section{ACKNOWLEDGMENTS}

This work was financially supported by the Research Council of Islamic Azad University Tonekabon Branch.

\section{REFERENCES}

Agellon L.B., Davies S.L., Chen T.T. and Powers D.A. (1988). Structure of a fish (rainbow trout) growth hormone gene and its evolutionary implications. Proc. Natl. Acad. Sci. U.S.A., 85:5136-5140.

Ber R. and Daniel V. (1993). Sequence analysis suggests a recent duplication of the growth hormone-encoding gene in Tilapia nilotica. Gene., 125:143-150.

Breatchez L., Guyomard R. and Bonhonme F. (1992). DNA sequence variation of the mitochondrial control region among geographically and morphologically remote European brown trout Salmo trutta populations. Mol. Ecol., 1(16) 1-173.

Chiou C.S., Chen H.T. and Chang W.C. (1990). The complete nucleotide sequence of the growth hormone gene from the common carp (Cyprinus carpio). Biochim. Biophys. Acta., 1087: 91-94.

Devlin R.H. (1993). Sequence of sockeye type 1 and type 2 growth hormone genes and the relationships of rainbow trout with Atlantic and Pacific salmon. Can. J. Fish. Aquat. Sci., 50:1738-1748.

Du S.J., Devlin R.H. and Hew C.L. (1993). Genomic structure of growth hormone genes in chinook salmon (Oncorhynchus tshawytscha): Presence of two functional genes. DNA Cell Biol.,12: 739-751.

Estoup A., Presa P., Krieg F., Vaiman D. and Guyomard R. (1993). (CT) and (GT) microsatellites: a new class of genetic markers for Salmo trutta L. (brown trout). Heredity, 71: 488-496.

Ferguson A. (1989). Genetic differences among brown trout, Salmo trutta, stocks and their importance for the conservation and management of the species. Freshwater Biol, 21: 35-46.

Ho W.K.K., Wong M.W. and Chan A.P.Y. (1991). Cloning and sequencing of the grass carp (Ctenopharyngodon idellus) growth hormone gene. Biochim. Biophys. Acta, 1090: 245-248.

Hong Y. and Schartl M. (1993). Sequence of the growth hormone (GH) gene from silver carp (Hypophthalmichthys molitrix) and evolution of GH genes in vertebrates. Biochim. Biophys. Acta, 1174: 285-288.

Gross R., Nilsson J, (1995). Application of heteroduplex analysis for detecting variation within the growth hormone 2 gene in Salmo trutta L.brown trout, Heredity, 74: 286-295.

Gross R., Schlee P., Stein H., Rottmann O. (1996). Detection of allelic variation within the growth hormone gene in common bream using heteroduplex analysis, J. Fish Biol, 48:1283-1287.

Johansen B., Johnsen O.C., Valla S. (1989). The complete nucleotide sequence of the growth-hormone gene from Atlantic salmon (Salmo salar). Gene (Amsterdam), 77: 317-324. 
Harvey S. (1995). Growth hormone synthesis. In: Harvey S, Scanes CG, Daughday WH, eds. Growth hormone. Boca Raton, FL: CRC Press; 55-78pp.

Ovenden J. R., Water R. and White R. W. G. (1993). Mitochondrial DNA nucleotide sequence variation in Atlantic salmon (Salmo salar), brown trout (S. trutta), rainbow trout (Oncorhynchus mykiss) and brook trout (Sa!velinus fontinalis) from Tasmania, Australia. Aquaculture, 114: 217-227.

Male R., Nerland A.H., Lorens J.B., Telle W., Lossius I. and Totland G.K. (1992). The complete nucleotide sequence of the Atlantic salmon growth hormone I gene. Biochim. Biophys. Acta, 1130:345-348.

Tanaka M., Toma Y., Ohkubo T., Sudo S. and Nakashima K. (1995). Sequence of the flounder (Paralichthys olivceus) growth hormone-encoding gene and its promoter region. Gene, 165:321-322.

Ohkubo T., Arai M., Tanaka M., Sudo S. and Nakashima, K. (1996). Molecular cloning and characterization of the yellowtail GH gene and its promoter: A consensus sequence for teleost and avian Pit-1/GHF-1 binding sites. J. Mol. Endocrinol, 16: 63-72.
Sambrook J., Fritsch E. F. and Maniatis T. (1989). Molecular cloning: a laboratory manual, 2nd edition. Cold Spring Harbor Laboratory Press, Cold Spring Harbor.

Tang Y., Lin, C.M., Chen T.T., Kawauchi, H., Dunham R.A., and Powers D.A. (1993). Structure of the channel catfish (Ictalurus punctatus) growth hormone gene and its evolutionary implications. Mol. Mar. Biol. Biotechnol. 2:198-206.

Venkatesh B., and Brenner S. (1997). Genomic structure and sequence of the pufferfish (Fugu rubripes) growth hormone encoding gene: A comparative analysis of teleost growth hormone genes. Gene, 187: 211-215.

Yowe D.L. and Epping R.J. (1995). Cloning of the barramundi growthhormone encoding gene: A comparative analysis of higher and lower vertebrate growth hormone genes. Gene, 162:255-259.

Zhu Z. He L. and Chen T.T. (1992). Primary-structural and evolutionary analysis of the growth-hormone gene from grass carp (Ctenopharyngodon idellus). Eur. J. Biochem, 207: 643648. 